\title{
ORGANIZATIONAL POLITICS AND WORKPLACE CONFLICT IN SELECTED TERTIARY INSTITUTIONS IN EDO STATE, NIGERIA
}

\author{
Chinedu Uzochukwu Onyeizugbe \\ Nnamdi Azikiwe University, Awka
}

Ishaq Musah

Nnamdi Azikiwe University, Awka

\&

Jonathan Obuebite

Nnamdi Azikiwe University, Awka

\begin{abstract}
The increasing rate of organisational politics and workplace conflict has been a great challenge to tertiary institutions in Edo State. This study examined how organisational politics affects workplace conflict among tertiary institutions in Edo State. The objective of this study is to examine the relationship that exists between self-interest and communication breakdown of selected tertiary institutions in Edo State. A total number of 369 copies of questionnaire was administered to the respondents domiciled in the six selected tertiary institutions under study (University of Benin, Benin city, Institute of Technology and Management, Usen, Ambrose Alli University, Ekpoma, College of Education, Igueben, Auchi Polytechnic, Auchi, Institute of Physical and Health Education, Afuze) using purposing sampling techniques and 343 copies of questionnaires were retrieved from the respondents. The study was guided by one research question and one hypothesis, correlational design was adopted. The data used was primary data collected through a structured questionnaire. The data collected was analyzed using descriptive statistics and the hypothesis was tested using Pearson product moment correlation with the aid of statistical package for social science (SPSS version 21). The findings revealed that there is a significant positive relationship between self-interest and communication breakdown among the selected tertiary institutions in Edo State and the researcher concluded that organisational politics will definitely lead to workplace conflict if not properly managed. The researcher recommended that the management of tertiary institution should put more effort in the supervision of staff so as to reduce the rate of organisational politics which measure is expected to increase employee performance, effective communication and employee output in the long run.
\end{abstract}

Keywords: Organizational Politics, Workplace Conflict, Self-interest, and Communication Breakdown

\section{Introduction}

The contemporary world is increasingly multicultural and the identity crisis resulting from this sometime threatens sustainable human development, which makes the promotion of understanding and dialogue to be a prime issue in the management of multiculturalism, organisational firms, global peace and security (Oloyede, 2009). Organisational politics and work conflict are inevitable in any organisation. Efficient and effective management of organisational politics and work conflict are fundamental to the development of any society, but the prevailing situations in Nigeria constitute a reversal of this reality (Uzoigwe, 2009). Work conflict is a term that refers to all expressions of dissatisfaction within the employment 
relationships, especially those pertaining to the employment contract, and the effort bargain. Conflict is a part of organisational life and may occur between individuals, between the individual and the group, and between groups which may arise as a result of organisational politics (Lammer, 2009).

According to Eze (2011) organisational politics is described as a self-serving behaviour which seeks to achieve self-interests, advantages and benefits at the expense of others. Organisational politics is an elusive type of power relations in the workplace. Organisational politics represents a unique domain of interpersonal relations, characterized by the direct or indirect (active or passive) engagement of people in influence tactics and power struggles (Wilson \& Judge, 2012). Organisational politics in tertiary institutions are frequently aimed at securing or maximizing personal interests or, alternatively, avoiding negative outcomes within the organisation (Ferris \& Kacmar, 2011). Workers in tertiary institutions always engage in the politic so as to achieve personal objectives. Though organisational politics is a correlate of work conflict, Udoye (2011) perceived conflict as dysfunctional, which may sometimes be beneficial because it may cause an issue to be presented in a different perspective.

Conflict has both positive and negative effects. It can be positive when it encourages creativity, increase in productivity, new looks at old conditions, exposes the leadership style, enhance employee turnover, level of customer satisfaction, the clarification of points of view, effective communication, introduce new ideas, reduces ego problem and development of human capabilities to handle interpersonal differences (Gerardi, 2011). Conflicts have become part of human organisations the world over. There are two major types of conflicts, internal and external. Internal conflict occurs between employees and their employers while external conflict occurs between employees and other bodies outside the organisation such as the government. Examples of internal conflicts abound between management and their employees in the universities while external conflicts occur between the university unions and the federal government. External conflicts seem to be the crux of the crises in the universities and they occur at alarming rates due to the diverse nature of the parties involved. The political nature of man, together with the fact that conflict is a global phenomenon in organisations, has made its occurrence in the universities an inevitable situation. However, what seems an aberration is the constant return to the resolution table with seemingly unending resolutions. The various unions in the federal universities are always in constant conflict with either the management or the federal government. These unions are the Academic Staff Union of Universities (ASUU), the Non-Academic Staff Union of Universities (NASU) and the Senior Staff Association of Nigerian Universities (SSANU).

Since the 1990s, it has become nearly impossible for universities to run an entire session without academic activities being disrupted by government-universities face off. In the South West, the federal universities have had to be closed for several months due to staff demands. From 2009 to 2017, there was hardly any semester that could boast of a conflict free calendar. Often, governments in Nigeria resorted to certain headline postures in order to counter ASUU's strike actions. These include banning and unbanning of the union, seizure of salaries under the guise of no work no pay, ejection from government quarters, detention, etc.

Other staff unions within the university system have often focused more on welfare and salary of members, rather than on the issues of funding and autonomy. Till date, ASUU is perhaps the only union that has signed comprehensive agreements with governments on the vexed issues of funding, autonomy and conditions of service. Onyeonoru and Bankole (2001) observed that 
much of the conflicts involving the governments and non-academic staff unions emanate from the collective agreements reached between the government and ASUU, which the unions often regard as exclusionary. These have led the popular parity conflicts in the universities that sometimes involve physical assaults.

At the institutional level, the relationship between university authorities and staff unions, especially the academic body, has also not been that rosy. Vice Chancellors in most Nigerian universities have often been in collision with unions on many issues, wide communication gap between the staff and the school authority, delay in meeting staffs demand by the school authority, withholding vital information by the school authority, lack of funding of various university projects, award of contract, repayment of outstanding allowances and salaries, purchase of facilities, library and laboratory materials, etc have sometimes caused some disharmony. Even when government allocates fund to the universities, cases have arisen when university authorities allocate fund money to things that have no bearing on teaching and learning. Olorode (2001) insists that the inability of most Vice Chancellors to effectively manage the resources available to their universities is due to the fact these people have acquired almost unlimited power to manipulate university resources according to their whims and caprices. This high rate of corruption in the university system, in his opinion, arises from the absence of democratic control of university administration.

In 1996, at Ogun State University (now Olabisi Onabanjo University), Ago-Iwoye, over one hundred academic staff were unilaterally sacked by the Vice Chancellor for their refusal to "sign back" during a nationwide strike called by the national body of ASUU. Thus, due to the fact that some Vice Chancellors became much too sensitive to criticism (Belo, 1998), and did not necessarily see themselves as accountable to anyone in the university, they effectively transformed into feudal lords within an environment designed to promote tolerance and freedom. This is a graphic description of what someone has called the winner takes-all syndrome. All these acts or arbitrariness and dictatorship have put ASUU on collision with the administration of many universities. Against this background the researchers sought to examine the relationship between organisational politics and workplace in selected tertiary institutions in Edo State.

Workplace conflict has been a problem to Nigerian organisations, tertiary institutions and private organisations especially towards their social development. It has been a dominant factor in the history of Nigeria labour relations. It has been observed that some of the causes of Academic Staff Union of Universities (ASUU) crises in tertiary institutions between the management or between the government and the civil servants include wide communication gap and withholding of vital organisational information as a matter of self-interest. The disagreement usually results in strike, lockout, which in one way or the other depends heavily on the service of the conflicting organisations. Work conflict sometimes arise in organisations from self- interest which normally occurs when employees are looking for personal benefit thereby leading to poor communication which result to communication breakdown, lack of compromise, poor orientation and poor leadership style. A high level of organisational politics has affected so many organisations as it leads to communication breakdown, low productivity, low employee output, low employee morale and poor employee commitment. Also, the problem of lack of cordial relationship has been a great challenge to organisations which leads to lower productivity. There has been a great set back in the turnover of some organisations which is as a result of strong negative perceptions of the employees. As a result of these 
perceived problems, this study therefore seeks to examine the relationship between organisational politics and workplace conflict of selected tertiary institutions in Edo State.

The broad objective of this study is to examine the extent of relationship that exists between organizational politics and workplace conflict among the selected tertiary institutions in Edo State, Nigeria. The specific objective is to determine the extent of relationship that exists between self-interest and communication breakdown in the selected tertiary institutions in Edo State. This is based upon an overarching research question - To what extent does self-interest affect communication breakdown in the selected tertiary institutions in Edo State?

This study covers organizational politics and workplace conflict of the six (6) selected tertiary institutions in Edo State with two from each of the three senatorial districts. The schools are: University of Benin City, Benin City (Edo South), Institution of Technology and Management, Usen (Edo South), Ambrose Alli University, Ekpoma (Edo Central), College of Education, Igueben (Edo Central), Auchi Polytechnic Auchi, (Edo North), Institute of Physical and Health Education, Afuze (Edo North). This research study decomposed organizational politics with self- interest and work conflicts with communication breakdown.

\section{Literature Review}

Okoli (2010) carried out a study on impact of violence on employee performance using two manufacturing companies in Lagos state. Two research questions guided the study and survey research design was adopted. The population of the study consisted of 170 staff. The data used was primary data collected through questionnaire and the data collected was analysed using simple percentages and ANOVA. The findings showed that violence has a negative impact on job satisfaction.

Henry (2006) examined the relationship between workplace conflict and employee performance using six manufacturing companies in Bangkok Thailand. Three research questions guided the study and survey research design was adopted. The data used was a primary data collected through structural questionnaire. The data collected was analysed using MINITAB 18 and the statistical tool used was Pearson correlation moment. The study revealed that there is a significant relationship between workplace conflict and workers' performance.

Baron (2009) examined the relationship between organisational politics and employee performance using Grenard Oil Production Company in Lagos as a case study. The study was guided by three research questions and the data used was primary data. The data collected was analysed using correlation. The study revealed that there is a significant relationship between organisational politics and employee performance.

Eze (2011) examined the effect of organisational politics on employee performance using Nigerian brewery in Enugu State as a case study. The study was guided by two research questions and descriptive survey research design was adopted. The data used was primary data collected from structured questionnaire. The data collected was analyzed using Z-test. The study revealed that organisational politics has a significant effect on employee performance. Wilson and Judge (2012) carried out a study on work politics as correlate of employee performance using four manufacturing companies. The study was guided by two research questions and descriptive survey research design was used. The data used was primary data collected through structured questionnaire. The data collected was analysed using Pearson 
product moment correlation. The study revealed that work politics has a negative relationship on employee performance.

Drory (1990) and Drory and Romm (1988) in their two field studies established that politics has a more deleterious impact on the attitude of low status employees and a less deleterious impact on the attitude of high-status individuals. Drory (1990) posited that this occurred because the higher status individuals were in a better position to shape and benefit from political decision making. Ferris and Kacmar (1992) and others found out that formal organisational processes are negatively related to perceived organisational politics. Moreover, scarce resources also encourage political involvement of employees while on the other hand sufficient organisational resources make achievement of disjointed goals a little easier. Further they continue to say that the likelihood of exhibiting political behaviour increases with the increase in role ambiguity, and goal ambiguity.

Buchanan \& Badham (1999), and Gray \& Ariss, (1985) observed that political behaviours play significant role in the organisational change process and that structural factors like; uncertainty and ambiguity, resource management, and redistribution of power, in the process of change in organisation simulate employee involvement in organisational politics.

According to Cropanzano (1997), employees who view the organisation as political in nature unequal or promoting only the aspirations of the powerful members may be encouraged to leave it physically and also psychologically, since organisational politics cause disengagement or psychological withdrawal of individuals. However empirical studies provide only marginal support for this idea.

Ferris (1993, 1996) and Bozeman (1996) established that those individuals who understand or can control political dynamics respond less negatively than those who lack understanding or control. These perceptions of politics were negatively related to job satisfaction and organisational commitment as identified by Drory (1993). Vogpda-Dadot (2003) found that workplace politics was perceived as self-serving behaviour by employees to achieve selfinterests, advantages, and benefits at the expense of others and sometimes contrary to the interest of the entire organisation or work unit. These results do not concur with the employees' job satisfaction and intensions to leave.

Aryee (2004); Byrne (2005); Chen and Fang (2007); Zivnuska (2004) provided evidence that organisational politics has direct influence on the job performance and that political perceptions were negatively related to affective commitment and job satisfaction. They were positively related to turnover intension and uncorrelated with continuance commitment. Politics was not significantly associated with performance. however, organisational support was positively related to affective commitment, job satisfaction, and job performance. Similarly, conclusion was drawn by Buchanan and Badham (2007) that employee involvement in organisational politics affects organisational performance, effectiveness, decision making and change processes.

Mao (2006) established that the organisational level and workplace friendship are negatively correlated. That is, employees of higher organisational level have weaker workplace friendship than employees of lower organisational level. 
Wen-Wei, Shih-Chin and Shih-I (2009) did not find any significant relationship between organisational level and perception of organisational politics, Nasir and (2009) essentially showed inconclusiveness between job status and job satisfaction. It would have seemed natural that those who are higher should fare better, but their results showed a mixed conclusion. Ofoegbu, Akanbi \& Alhanolu (2012) established that there was a strong association between pay and promotion policy and job satisfaction. Further, there is positive association between perception of organisational politics and workplace friendship.

Gotsis \& Kortezi (2010) study established that organisational politics was negatively related to performance of organisation. Similarly, other studies established that managers are positively related to the involvement of organisational politics. These studies concluded that managers who are highly involved in organisational politics were found to be achieving goals of organisation with the help of organisational politics. Therefore, managerial involvement in organisational politics was proposed to be necessary for the survival of the organisation (Madison, 1979).

Other empirical conclusions of interest to this paper are that organisational politics is negatively related to the employee perception about the fairness and justice in the organisational processes (Andrews \& Kacmar, 2001; Aryee, Chen \& Budhwar, 2004; Beugre\& Liverpool, 2006; Ferris, 1999). Drory and Beaty (1991) also suggested that gender should be investigated as a variable which potentially affects the attitude and behaviour of organisational members with regard to organisational politics and that the possible unique effect of internal politics on public agencies and public servants is still unclear and deserves more attention.

Wiyy (2011) carried out a study on perception of organisational politics on employee output using three oil producing companies in Malaysia. The study was guided by two research questions and descriptive survey research design was adopted. The data used was primary data collected through structured questionnaire. The data collected was analysed using T-test. The study revealed that organisational politics has a significant effect on employee output.

Organisational Politics can be understood in terms of what people think of it rather than what it actually represents and therefore politics in organisations reflect the organisational climate. Organisational politics and power have been regarded as critical factors affecting various organisational practices (Klim, 2004). However, Morgan (1998) added that organisation is a premise composed of people who have varied task, career, and personal interests which allows us to understand it as a political entity.

Politics is the process of making decision applying to all members of each group. More narrowly, it refers to achieving and exercising positions of organized control over a human community. Politics is the study practice of the distribution of power and resources within a given community (usually a hierarchically organized population or in a working environment) as well as the interrelationship(s) between communities (Ferris \& Kacmar, 2011). A variety of methods are deployed in politics, which include promoting or forcing one's own political views among people, negotiation with other political subjects, making laws, and exercising force, including warfare against adversaries. Politics is exercised on a wide range of social levels, from clans and tribes of traditional societies through modern local governments, companies and institutions up to sovereign states, to the international level. It is very often said that politics is about power. A political system is a framework which defines acceptable political methods within a given society (Wiyy, 2009). 
Organisational politics is an important ingredient of the life of any organisation, which refers to behaviour in which personal interests are safeguards rather than organisational interests. The concept of organisational politics, well established now, has been well defined by Ferris and Kacmar (2011) and they viewed it as the amount to which employees observe their work setting as political in nature which results to making them feel their environment unfair and unjust". The nature of behaviour of employees working within an organisation is frequently considered as political and this political environment affect the nature and behaviour of the employees.

Organisational politics perceptions in worksites have been viewed as and empirically evident of its negative relationship with job satisfaction (Anthony \& Cleveland, 2009), organisational commitment and job performance (Anderson, 2004). Vigoda, (2002) concluded that these negative perceptions about organisational politics make employees feel they are working in an unjust and unfair environment which make them dissatisfied and as a result they are compelled to quit the organisation. When there is unfair environment, reciprocating does not pay equitable reward anymore. Vigoda (2002) opined that employees visualize that while they are putting great deal of efforts working in organisation, such type of efforts or investment expecting future returns are not fair so the likelihood of disharmonious exchange relationship emerges.

\section{Organisational Politics and Job Performance}

Definition of job performance as a variable in empirical research and its acclaimed relevance in the field of industrial or organisational psychology (Sonnetag \& Frese, 2002) differs across researchers. Viswesvaran (2001) attributes this dissimilarity to the characteristic of its being an abstract and latent construct with many manifestations - a notion supported by Motowidlo (2003). Performance is a multidimensional construct where different types of behaviours need to be considered in order to understand it (Aguinis, 2005). Literature has related employees' performance in organisations based on two perspectives namely task performance and contextual performance (Borman, 2007). Task performance refers to two activities mainly: (1) activities that transform raw materials into goods and services in organisations, and (2) activities that help with the transformation process by for example providing planning, coordination and supervision to ensure organisation efficiency and effectiveness (Casio \& Aguinis, 2005). Accordingly, skills and abilities are the two main factors that contribute to task performance.

Meanwhile contextual performance refers to behaviours that influence the effectiveness and efficiency of organisation. Aguinis (2005) suggested that good environment in which task performance can occur will help to achieve these goals. Additionally, personality is one of the important aspects that play significant role in influencing contextual performance. among the characteristics, as suggested by Aguinis, (2005) are: (1) persisting with enthusiasm and exerting extra effort to complete task activities, (2) volunteering to carry out tasks/activities that are not formally part of the job, (3) helping and cooperating with others, (4) following organisational rules and procedures, and (5) endorsing, supporting and defending organisational objectives.

Based on the above, it can be concluded that both task performance (TP) and contextual performance $(\mathrm{CP})$ are important especially in managing performance of employee in organisation. Aguinis, (2005) supports that task performance (TP) and contextual performance (CP) is an important dimension of performance management system to ensure organisational efficiency, effectiveness and performance. This study focused the definition of job performance based on two dimensions mainly task performance (TP) and counterproductive work behaviour (CWB). Task performance as defined by Borman and Motowidlo (1997) has five dimensions 
that include 1) job-specific task proficiency, (2) non-job-specific proficiency, (3) written and oral communication proficiency, (4) supervision - in the case of a supervisory or leadership position, and (5) management. In contrast to task performance, Adams (1999) and O'Brien and Allen (2008) suggested that voluntary behaviour that are deviant and damaging to the organisational goals which are considered in negative form are also a part of employees' performance construct.

\section{Communication}

Performance of any organisation will never come to success if there is a poor communication process. Any organisation without effective communication process will always lag behind. A listener takes delivery of the message and must be an active listener. Effective communication takes place only when the listener clearly understands the message that the speaker intended to send. According to Okoli (2010) effective communication is a two-way information sharing process which involves one party sending a message that is easily understood by the receiving party. Effective communication by business managers facilitates information sharing between company employees and can substantially contribute to its commercial success. Effective communication is not merely about exchanging information between you and your audience. It is about making what you want to say, what you actually say and what your audience interprets, consistent. The goal of effective communication is to create a common perception that is received in a positive manner, so that the organisation can together agree on a further action or decision. The importance of effective communication relies on the fact that it reduces misunderstandings or the possibility of overlooking important information. This ultimately saves time as situation can be assessed accurately and can also save organisation from potential embarrassment of assuming things that are incorrect (Drucker, 2011).

\section{Self-interest}

Self-interest refers to actions that elicit the most personal benefit. It can also be explained as the best economic benefit one can accomplished when individuals act in their own self-interest (Guerico, 2010). Guerico explanation of the invisible hand reveals that when dozens or even thousands act in their own self-interest, goods and services are created that benefit consumers and producers. According to Adams (1999) in a market economy, individuals own most of the resources available, labour, land and capital, and use voluntary decisions, made in self-interest, to control the marketplace. In this type of system, the government plays a small role and the economy is shaped by two forces, self-interest and competition. Self-interest is arguably the single largest motivator of economic activity. In his book covering the subject, "The Wealth of Nations", Adam Smith describes that self-interest can cause the following:

- Self-interest causes us to create negative karma

- Self-interest prevents us from achieving our goals

- Self-interest makes us extremely sensitive and easily offended

- Self-interest makes us feel guilty and engage in self-pity

- Self-interest causes fear

According to Adams (1999) traditional economic theory assumes that human behaviour is driven by self-interested pursuits. This assumption appears valid because there is direct link between outcomes that benefit the self and happiness: simply put, people feel good when their lot in life improves and we feel bad when it worsens. Moreover, the relationship between selfinterested pursuits and happiness is complicated (Hsee \& Hastie, 2006). 


\section{Conflict}

Conflict has its origin in differences in objectives, interest efforts, approaches, timing attitudes and others. Conflict is defined as an overt behaviour arising out of a process in which one unit seeks the advancement of its own interest in its relationship with others (Lammer, 2009). The interference must be deliberated and goal directed by, at least, one part. This concept of conflicts incorporates such protest movements in formal organisations as promotion of interest, session and seizure of power. Conflict has also been defined as a situation of disagreement between two parties (Amusan, 2006). Accordingly, a conflict situation is characterized by the inability of those concerned to iron out their differences and reach an agreement on issues of common interest. Ejiogu (2000) also perceived conflict as mutual hostility and all kinds of opposition or antagonistic interaction including disagreements or controversies about ideas, values, and ways of life.

\section{Workplace Conflict}

According to Gerardi (2011) workplace conflict is an expression of dissatisfaction within the employment relationship especially those pertaining the employment contract and the collection bargaining. Also, Marshall (2004) viewed workplace conflict as resulting from the incompatible interest of workers and employers in the workplace; disagreement arising when the terms and the conditions of employment clash resulting from opposing views held by the management participant in the workplace fashioned according to their steps and positions on the organisational location.

\section{Conflict Management}

Conflict management is the process of limiting the negative aspects of conflict while increasing the position aspects of conflict. The aim of conflict management is to enhance learning and group outcomes, including effectiveness or performance in organisational setting (Udoye, 2011). It can also be explained as the practice of recognizing and dealing with disputes in a rational, balanced and effective way (Oloyede, 2009). Conflict management implemented with a business environment usually involves effective communication, problem resolving abilities and good negotiating skills to restore the focus to the company's overall goals. Organisational conflict at the interpersonal level includes dispute between peers as well as supervisorsubordinate conflict (Gerardi, 2011). According to Hickman, (2010) Party-Directed Mediation (PDM) is a mediation approach particularly suited for disputes between co-workers, colleagues or peers, especially deep-seated interpersonal conflict, multicultural or multi-ethnic disputes. The mediator listens to each party separately in a pre-caucus, coaching and role play formats. The idea is that the parties learn how to converse directly with their adversary in joint session. Some unique challenges arise when organisational disputes involve supervisors and subordinates. The Negotiated Performance Appraisal (NPA) is a tool for improving communication between supervisors and subordinates and is particularly useful as an alternative mediation model because it preserves the hierarchical power of supervisors while encouraging dialogue and dealing with differences in opinion (Dana, 2003).

\section{Types of Organisational Conflict}

Udoye (2011) observed that organisational conflict involves interpretational conflicts with colleagues or supervisors, or intergroup conflicts with different sections of an organisation. There are two essential types of conflict in organisations: vertical and horizontal. Vertical conflict occurs in groups of different hierarchy levels, such as supervisors and salesmen, whereas horizontal conflict occurs between individuals of the same level, such as manages in the same organisation. In the vertical conflict, differences in status and power between groups 
are in general larger than in the horizontal conflict because these aspects tend to equalize in equivalent hierarchical levels (Okoli, 2010). When vertical conflict takes place between operational workers and administration, their sources refer to:

- psychological distance: workers do not feel involved in the organisation and feel that their needs are not met.

- power and status: workers felt powerless and alienated.

- differences in value and ideology: this difference represents underlying beliefs on objectives and goals of an organisation.

- scarce resources: disagreements regarding benefits, salary and work conditions.

In vertical conflict, apparently individuals in lower organisational level seek to avoid conflicts with higher hierarchical levels (Mitchell \& Weber, 2002).

\section{Conflict between Staff Unions and Management of Tertiary Institutions}

Five prominent unions are recognized within the universities in Nigeria. They are the Academic Staff Union of Universities (ASUU)/Academic Staff Union of Polytechnics (ASUP), Senior Staff Association of Nigeria Universities (SSANU)/Senior Staff Association of Nigeria Polytechnics (SSANIP), and Non-Academic Staff Union (NASU). The major objective of these unions is to protect the welfare of their members. On Academic Staff Union of Universities (ASUU), for instance, Iyayi (2002) says the union is a trade union which like other trade unions is a "combination of workers and employers, whether temporary or permanent, the purpose of which is to regulate the terms and conditions of the employment of workers". In specific terms, Iyayi outlined the principles that guide academic staff as a union as follows:

- Integrity, transparency and accountability,

- Professionalism, objectivity and hardwork,

- Courage, sacrifice and total equipment,

- Internal democracy, teamwork and group solidarity, as well as

- Patriotism, anti-imperialism and working-class solidarity.

In carrying out these principles, academic staff has been at loggerheads with tertiary institution authorities. Authors and researchers had attributed the incessant conflicts in tertiary institutions in Nigeria to many factors, such as: lack of implementation of national agreements violation of local agreements or non-provision of basic facilities and poor staff welfare; non-provision of municipal services (i.e., electricity, water and telecommunication), poor sewage and refuse disposal (Odewunmi, 2003).

According to UNESCO (1997) facilities play crucial role in the efficacy of tertiary education. The issue of inadequacy and decayed infrastructural facilities in tertiary institutions in Nigeria abound in literature. While classrooms in most tertiary institutions in Nigeria are inadequate for the population of students and for effective teaching and learning, staff offices are also inadequate and poorly equipped for comfortable living of staff. Staff quarters are also insufficient for staff while many are substandard. It needs not be overemphasized that in a tertiary institution, there are supposed to be regular supply of utilities such as electricity and water, to ensure comfortable living of staff living within the campus. There should also be regular refuse and waste disposal in the campuses. When these are not carried effectively, it usually leads to conflict by staff. Attitudes of tertiary institutions' administrators also leaves 
much to be desired. Many administrators have turned to 'tin gods' in campuses. Students and staff dare not challenge them on any issue or policy/programme. Promotion of staff has been unnecessarily delayed, due to internal conflict with senior management. Many policies in tertiary institutions have not been staff and management friendly. All these make staff to come into conflict with management.

\section{Victimization of Staff of Tertiary Institutions}

The case of the forty-four (44) lecturers at University of Ilorin (one of the Universities in Nigeria) few years ago which generated controversies and led to strikes in many universities, is another example. The lecturers were dismissed for joining their colleagues in other tertiary institutions, to embark on strike, to press home their demand for increased welfare packages. Within the last decade, a particular Head of State in Nigeria, also gave the order that any lecturer in any of the universities in Nigeria who refused to resume from strike they embarked on then, should be ejected from his/her quarter. What seems to be a joke initially was eventually implemented where many lecturers were beaten by law enforcement agents and their properties thrown out of their quarters. It took the intervention of some influential citizens of the country to resolve the issue amicably. This action of government however forced many lecturers into exile where they felt their safety will be guaranteed.

\section{Low Wages/Poor Conditions of Service}

In Nigeria, salaries of lecturers of tertiary institutions are very low relative to what their counterparts earn in foreign countries. A survey by National Universities Commission (NUC) in 2007 revealed that a full professor in Botswana earned US\$27,000 per annum, between US $\$ 21,000$ and US\$35,000 in Namibia, between US\$65,000 and US $\$ 75,000$ in South Africa. In the case of Nigeria, a full professor earned about US\$12,000 as at year 2006. It is disheartening to note that the salary of a full professor in Nigeria is not up to that of a fresh graduate in the oil and banking sectors. Nigeria is even a country where the annual salary of a university professor is not up to the amount being spent to hire a coach to train footballers. To worsen situation, there has been irregularity in the payment of staff emoluments. Many strikes had been observed in the past due to inability of government to pay the salaries and allowances of staff as and when due. In the recent past, staff of many tertiary institutions were at loggerheads with government, due to non-payment of their 'monetization arrears' which was promised to be paid to workers by the last civilian government, following the introduction of the obsolete monetization policy in the country. Agitation for increases in salary and allowances has thus continued to dominate the demands of trade unions from government. Unfortunately, staff of tertiary institutions in Nigeria have been turned to dogs that must bark before being given food to eat.

\section{Theoretical Framework}

While two theories (Theory of procedural justice and humanistic theory) are discussed in this study, the emphasis was on the latter.

\section{Procedural Justice Theory}

Studies by Ferris (1996); Folger, Konovsky and Cropanzano (1992) used the theory of procedural justice to argue that organisational politics is related to the efficiency of human resource systems and to decision-making processes. Lack of minimal justice and fairness in these systems is found a main cause of higher perceptions of organisational politics and therefore hampers organisational outcomes. All these studies relied on Kurt Lewin's (1936) argument that people respond to their perceptions of reality, not to reality itself. Likewise, 
politics in organisations should be understood in terms of what people think of it rather than what it actually represents. Studies thus proposed that perceptions of justice and fairness reflect a political eliminate in the workplace and may also be related to a variety of work outcomes. Ferris, Kacmar and their colleagues (1992) extensively advocated these ideas in numerous studies. The procedural justice theory becomes relevant to this study as it relates organisational politics to human behaviour in a typical workplace environment. The study shows how academic staff of sampled institutions conflicts bring about efficiency in the management of such institution's resource in order to attain the organisational goals.

\section{Humanistic Theory}

According to humanistic theory of Albert Ellis (1991), people have strong inclination to live and be happy, to seek pleasure and avoid pain. They are goal oriented, active and changing creation with a strong compulsion to fulfil their potentials. The theory also explained that for dispute to occur in a working environment there must be a source of inclination. However, people of the same ages engage in numerous irrational thoughts, unsuitable, and dysfunctional behaviours that are inclined to sabotage their potentials. People are born with a distinct proneness to engage in self-destructive behaviour and learn through social conditioning to exacerbate rather than minimize their proneness. People grow up in social groups and spend much of their energy trying to impress, live up to the expectation of and outdo the performance of others. On the surface, they are 'ego oriented', identity seeking, or self-centred. Even more importantly, however, they usually define themselves as good or worthwhile when they believe that others accept and approve of them. Ellis says that it is realistic and sane for people to find or fulfil themselves in their interpersonal relations and to have a considerable amount of what is referred to by Adler as social interest so as to avoid either organisational conflict or violence in any environment. This theory relates to this study as it helps to describe how dispute in a typical workplace could create happiness, pleasure, and avoid pain in the life of academic staff. Thus, academic staff are seen as people of the same "mindset" or "ages" engaging in irrational thoughts during the period of conflicts which could incline to sabotage their potentials.

This study examines organisational politics and workplace conflict among selected tertiary institutions in Edo State. The study reviewed the meaning of organisational politics, conflict, workplace conflict and conflict management. Organisational politics was explained as the amount to which employees observe their work setting as political in nature which results to make them feel their environment unfair and unjust. Conflict was explained as an overt behaviour arising out of a process in which one unit seeks the advancement of its own interest in its relationship with others. Workplace conflict was explained as an expression of dissatisfaction within the employment relationship especially those pertaining to employment contract and collective bargaining. Conflict management was also explained as the process of limiting the negative aspects of conflict while increasing the positive aspects of conflict.

The study was anchored on humanistic theory by Albert Ellis (1991), which explained that for dispute to occur in a working environment there must be a source of inclination. However, related studies on organisational politics and conflict management were reviewed but no study on employee self-interest and communication breakdown was done on tertiary institution using Nigeria's data which is the gap the study seeks to cover.

\section{Methodology}

The study adopted correlational research design method. This is the premise as it allows the researcher to determine the strength and direction of a relationship that exists between self- 
interest and communication breakdown in the selected tertiary institutions in Edo State. The population of this study comprises twelve (14) tertiary institutions as of 2017 in Edo State, Nigeria with the total number of 5,703 academic staff.

Table 1: List of Tertiary Institutions and their Number of Academic staff in Edo State

\begin{tabular}{|l|l|l|}
\hline S/No & Institutions & No of Staff \\
\hline 1. & Auchi Polytechnic, Auchi Edo State & 1150 \\
\hline 2. & Edo State College of Agriculture, Iguoriakhi & 90 \\
\hline 3. & Wellspring University, Edo State & 125 \\
\hline 4. & School of Health Technology, Afuze & 61 \\
\hline 5. & Igbinedion University Okada & 120 \\
\hline 6. & University of Benin, Benin City & 2236 \\
\hline 7. & Samuel Adegboyega University, Ogwe & 160 \\
\hline 8. & College of Education, Ekiadolor, Benin & 118 \\
\hline 9. & Edo State Institute of Technology and Management, Usen, Benin City & 249 \\
\hline 10. & Edo University, Iyamho & 107 \\
\hline 11. & Ambrose Alli University, Ekpoma & 982 \\
\hline 12. & Edo State College of Education, Igueben & 159 \\
\hline 13. & Shaka Polytechnic, Benin City, Edo State & 126 \\
\hline 14. & Benson Idahosa University, Benin City & 120 \\
\hline & Total & $\mathbf{5 , 7 0 3}$ \\
\hline
\end{tabular}

Field Survey, 2018

The table above is a list of all the tertiary institutions in Edo State. Among the six states in South-south geo-political zone, Edo State boasts of the largest number of tertiary institutions, a scenario which arguably justifies its choice for the study.

Therefore, the target population of this study consists of academic staff of the six (6) selected tertiary institutions which is 4837 . Out of which the designed sample $n=369$ was obtained from Taro Yamane formula cited in Omoankhanlen and Osagie (2007).

Where:

$$
\begin{aligned}
& n=\frac{N}{1+N(e)^{2}} \\
& \mathrm{n}=\text { desired sample size } \\
& \mathrm{N}=\text { population of study } \\
& \mathrm{E}=\text { allowed margin of error }=5 \% \\
& 1=\text { constant } \\
& n=\frac{4837}{1+4837(0.05)^{2}}
\end{aligned}
$$$$
n=\frac{4837}{1+4837(0.0025)}
$$ 


$$
\begin{aligned}
& n=\frac{4837}{1+12.0925} \\
& n=\frac{4837}{13.0925} \\
& n=369
\end{aligned}
$$

The table below presents institutions and their respective number of academic staff.

Table 2: Institutions and their respective number of academic staff $(Q 2,2017)$

\section{S/No Institutions}

1. University of Benin, Benin City (Edo South)

2. Institution of Technology \& Management, Usen (Edo South)

3. Ambrose Alli University, Ekpoma (Edo Central)

4. College of Education Igueben, (Edo Central)

5. Auchi polytechnic, Auchi (Edo North)

6. Institute of Physical and Health Education,

$$
\begin{aligned}
& \text { Afuze, (Edo North) } \\
& \text { Total }
\end{aligned}
$$

Source: Field Survey, 2017

$\begin{array}{lc}\text { No of Staff } & \begin{array}{c}\text { Sampled Across } \\ \text { Institution }\end{array} \\ 2236 & 170 \\ & \\ 249 & 19 \\ 982 & 75 \\ 159 & 12 \\ 1150 & 88 \\ & \\ 61 & 5 \\ \mathbf{4 8 3 7} & \mathbf{3 6 9}\end{array}$

Purposive sampling technique was used to select the number of tertiary institutions in Edo State used for this study because for easy availability of data, convenience, interest of the researcher and quick access to information for intensive study on the principles that they can be representative of the entire population used for the study. Taro Yamane's statistical formula was used in determining the sample size, the techniques are scientific hence is objective in nature. The sample size of 369 was chosen without any deliberate discrimination. That every academic staff in the six (6) selected tertiary institutions in Edo State had an equal chance to be included in the study.

The data used in this research study was primary data collected through a structured questionnaire. The researchers visited the six (6) sampled tertiary institutions in Edo State, and administered the questionnaires personally with the help of the academic staff in the schools requesting to complete it as truthfully as they could. The completed copies of the questionnaire were collected immediately after the respondents completed the questionnaires.

The questionnaire was developed by the researchers on the basis of the research question and it was divided into two parts. Part one comprised general information resulting to the respondents; part two was designed to get information on self-interest and communication breakdown. A total of 369 copies of the questionnaire were administered to respondents out of which only $95 \%$ (i.e., 343 copies were duly filled and returned. i.e. the respondents of University of Benin, Benin City received 170 questionnaires out of which 158 were filled and returned, Institute of Technology and Management, Usen, received 19 questionnaires out of which 19 were filled and returned, Ambrose Alli University Ekpoma, received 75 questionnaire out of which 70 were filled and returned, College of Education, Igueben received 12 
questionnaire out of which 12 were filled and returned, Auchi Polytechnic, Auchi received 88 questionnaires out of which 79 were filled and returned, and Institute of Physical and Health Education, Afuze received 5 questionnaires out of which 5 were filled and returned and this will bring a total of 343 copies of the questionnaire were retrieved from the respondents in the six (6) selected tertiary institutions in Edo State, Nigeria on which the research analysis was based.

A 5-point Likert scale of 1 to 5 was used to measure the extent to which the various respondents agreed or disagreed with the issues raised. i.e., Strongly agree $(\mathrm{SA})=5$; Agree $(A)=4$, Disagree $(\mathrm{D})=3$, Strongly Disagree $(\mathrm{SD})=2$, Undecided $(\mathrm{U})=1$.

To ensure the validity of the questionnaire, the questionnaire together with the objectives of the study and hypothesis were sent to two experts and specialists in the field of research at Faculties of Management Sciences. This was to establish that the instrument was the appropriate one for measuring the variables contained in the study. The instrument was judged to have both face and content validity. The opinions and advice of these experts and specialists were highly considered in preparation of the final draft of the questionnaire.

To determine the reliability of the instrument, a test-retest method was employed in testing for the reliability of the instrument. To determine the reliability of the questionnaire, the Spearman Rank Order Correlation Coefficient was used to assess the strength of the relationship between the two sets of results from the copies of questionnaires. The Spearman Rank Order Correlation Coefficient formula is given below:

$\mathrm{r}_{\mathrm{S}}($ or P $)=1-\frac{6 \sum d^{2}}{N^{3}-N}$ OR $1-\frac{6 \sum d^{2}}{N\left(N^{2}-1\right)}$

where, $\mathrm{r}_{2}=$ Spearman Rank Order Correlation Coefficient.

$1=$ Unity i.e., perfect correlation from which any value in the quality may be taken to reduce the coefficient

$6=$ This is the constant value

$\sum d^{2}=$ The sum of the difference in ranks squared

$\mathrm{N}=$ Number of cases

Decision Rule: Accept the instrument if the value is $\geq 0.5$. 


\section{Table 3: Test and Re-test table value for the Instrument}

$\begin{array}{ccccc}\text { S/No. } & \text { Pre-test } & \text { Post-test } & \text { D } & \text { d2 } \\ 1 & 10 & 7 & 3 & 9 \\ 2 & 6 & 8 & 2 & 4 \\ 3 & 8 & 8 & 0 & 0 \\ 4 & 2 & 7 & 5 & 25 \\ 5 & 4 & 7 & 3 & 9 \\ 6 & 10 & 6 & 4 & 16 \\ 7 & 15 & 14 & 1 & 1 \\ 8 & 12 & 6 & 6 & 36 \\ 9 & 4 & 6 & 2 & 4 \\ 10 & 0 & 5 & 4 & 16 \\ 11 & 5 & 3 & 2 & 4 \\ 12 & 5 & 7 & 2 & 4 \\ 13 & 0 & 2 & 2 & 4 \\ 14 & 15 & 10 & 5 & 25 \\ 15 & 14 & 12 & 2 & 4\end{array}$

Total

Source: Field Survey, 2017

170

Using the Spearman Rank Correlation Coefficient formula, the reliability of instrument was calculated as thus: $1-\frac{6 \sum d^{2}}{N\left(N^{2}-1\right)}$

$$
\begin{aligned}
\mathrm{r}_{2} & =1-\frac{6 \sum d^{2}}{N\left(N^{2}-1\right)} \\
& =1-\frac{1020}{15\left(15^{2}-1\right)} \\
& =1-\frac{1020}{3360} \\
& =1-0.3036 \\
& =0.6964
\end{aligned}
$$

After the computation, the reliability of 0.69 was obtained. This was considered high enough for the instruments to be considered reliable.

\section{Data Analysis}

The data analysis was performed quantitatively using the statistical package for social science (SPSS, version 21). The data collected were also subjected to descriptive statistics which includes frequencies, means, and percentage. Interpretation of the data was done within the frame of reference of the research problem. The relationship between variables was established using the Pearson correlation tests (r, correlations). Pearson correlation product moment was used to test the hypothesis at 0.05 level of significance. The correlation formula is given below:

$$
\mathrm{r}^{2}=\frac{n \sum x y-\sum x \sum y}{\left(n \sum x^{2}-\sum(x)^{2}\right)\left(n \sum y^{2}-\sum(y)^{2}\right)}
$$




$$
0<\mathrm{r}^{2}<1
$$

In this study, $\mathrm{r}^{2}$ is used to determine the relationship between the sub-variables.

Decision rule: We do not reject the alternative hypothesis when the probability value is less than alpha otherwise reject.

\section{Table 4: Self-interest}

S/N Self- interest

1. I always work to satisfy

myself not

others

2. I always make sure I benefit from whatever I do.

3. My primary concern is always what I can gain from what I do.

4. I will satisfy customers as long as there is something I can gain from it.

5. I always do my job the way it pleases me.

6. When salaries are not paid, I find difficult to carry out my responsibilities as an academic staff of the university.

7. I will always put in my best when I can derive personal benefit from my work place.

\section{SA}

177(48\%)

A D

SD

$\mathbf{U}$

Total

$\begin{array}{lllll}120(32 \%) & 26(7 \%) & 36(10 \%) & 10(3 \%) & 369(100 \%)\end{array}$

$146(62 \%) \quad 68(18 \%) \quad 21(6 \%)$

52(13\%) 369(100\%)

$109(30 \%) \quad 47(13 \%) \quad 31(8 \%)$

$146(39 \%)$

$187(51 \%) \quad 130(35 \%) \quad 16(4 \%) \quad 7(10 \%)$

$369(100 \%)$

$\begin{array}{llllll}177(48 \%) & 120(32 \%) & 26(7 \%) & 36(10 \%) & 10(3 \%) & 369(100 \%)\end{array}$

$187(51 \%) \quad 130(35 \%) \quad 16(4 \%) \quad 7(10 \%)$

$369(100 \%)$

\section{Source: Field Survey, 2017}

From the analysis above, 48 percent of the respondents strongly agree that they always work to satisfy themselves not others, 32 percent agree, 2 percent were undecided, 7 percent disagree while 10 percent of the respondents strongly disagree that they always work to satisfy themselves not others. The analysis above shows that 62 percent of the respondents strongly 
agree that they always make sure they benefit from whatever they do, 18 percent agree, 13 percent were undecided, while 6 percent of the respondents disagree that they always make sure they benefit from whatever they do.

From the analysis above, 39 percent of the respondents strongly agree that their primary concern is always what they can gain from what they do, 35 percent agree, 10 percent were undecided, 13 percent disagree while 8 percent of the respondents strongly disagree that their primary concern is always what they can gain from what they do. From the analysis above, 51 percent of the respondents strongly agree that they satisfy customers as long as there is something, they can gain from it, 35 percent agree, 4 percent disagree while 10 percent of the respondents strongly disagree that the satisfy customers as long as there is something, they can gain from it.

The analysis above shows that 48 percent of the respondents strongly agree that they always do their job the way it pleases them, 32\% agree, 77 disagree, while 10\% strongly agree and $37 \%$ undecided that they always do their job the way it pleased them. From the analysis above, 51 percent of the respondents strongly agree that when salaries are not paid, they find it difficult to carry out their responsibilities as an academic staff of the institution, 35\% agree, 47 disagree and 10 percent strongly disagree. From the analysis above, 39 percent of the respondents strongly agree that they will always put in their best when they can derive personal benefit from their workplace, 30 percent agree, 13 percent disagree, while 8 percent strongly disagree and 10 percent undecided. 
Table 5: Responses on Communication Breakdown

SA

\section{breakdown}

$\begin{array}{llllll}\text { 1. In my institution, } 213(58 \%) & 104(28 \%) & 10(3 \%) & 16(4 \%) & 26(7 \%) & 369(100 \%)\end{array}$ no effort is made

to help us

understand

instruction

2. I am usually left to obey instructions the way I understand them.

3. There is no understanding between me and my boss

4. I find difficult to understand what is required of me.

5. The channel of $109(35 \%) \quad 146(39 \%) \quad 83(23 \%) \quad 31(8 \%)$ communication in my institution is always informal in nature.

6. I find it difficult to give feedback to my head of department

7. I find it difficult to understand my responsibilities as a result of poor communication channel in my institutions.

8. As a member of $21(30 \%) \quad 28(39 \%) \quad 16(23 \%) \quad 6(8 \%)$ $369(100 \%)$ $187(51 \%) \quad 83(22 \%) \quad 26(7 \%) \quad 73(20 \%)$ $369(100 \%)$

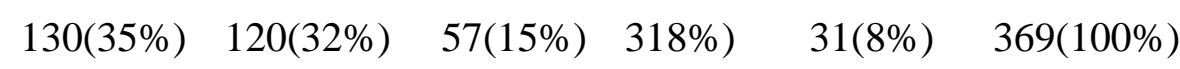
(1)

\section{SA}

A

D

SD

$\mathbf{U}$

Total

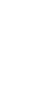


The analysis above shows that 58 percent of the respondents strongly agree that their institution effort is made to help them understand instruction, 28 percent agree, 7 percent were undecided, 3 percent disagree while 4 percent of the respondents strongly disagree that their institution effort is made to help them understand instruction.

Again, 51 percent of the respondents strongly agree that they are usually left to obey instructions the way they understand them, 22 percent agree, 7 percent disagree while 20 percent of the respondents strongly disagree that they are usually left to obey instructions the way they understand them. Also, 35 percent of the respondents strongly agree that there is no understanding between them and their boss, 32 percent agree, 8 percent were undecided, 15 percent disagree while 8 percent of the respondents strongly disagree that there is no understanding between them and their boss.

The above analysis also shows 30 percent of the respondents strongly agree that they find it difficult to understand what is required of them, 39 percent agree, 23 percent disagree while 8 percent of the respondents strongly disagree that they find it difficult to understand what is required of them. The above analysis shows 35 percent of the respondents strongly agree that the channel of communication in my institution is always informal in nature; 39 percent agree, $23 \%$ were undecided while $8 \%$ of the respondents strongly disagree that the channel of communication in my institution is always informal in nature.

From the analysis above, 39 percent of the respondents strongly agree that they find it difficult to give feedback to their heads of department, 30 percent agree, 13 percent disagree, 8 percent strongly disagree and 10 percent undecided. The above also shows that 48 percent of the respondents strongly agree that they find it difficult to understand their responsibilities as a result of poor communication channel in my institutions, 32 percent agree, 7 percent disagree, while 10 percent strongly disagree and 3 percent undecided. From the above analysis 62 percent of the respondents strongly agree that as a member of ASUU the find it difficult to understand the co-existence of the Union and Management of the institutions.

Testing of hypothesis was undertaken using Pearson Product Moment Correlation with aid of Statistical Package for Scientific Studies (SPSS Version 21)

$H_{1}$ : There is significant relationship between self-interest and communication breakdown in the selected tertiary institutions in Edo State.

\begin{tabular}{|l|l|l|l|}
\hline \multicolumn{2}{|c|}{ Descriptive statistics } \\
\hline & Mean & Std. Deviation & N \\
\hline Self- interest & 14.200 & 8.4352 & 5 \\
Communication breakdown & 14.200 & 10.3396 & 5 \\
\hline
\end{tabular}




\section{Correlation}

\begin{tabular}{|l|l|l|l|}
\hline & & Self- interest & $\begin{array}{l}\text { Communication } \\
\text { breakdowns }\end{array}$ \\
\hline Self- interest & Pearson Correlation & 1 & .839 \\
& Sig. (2-tailed) & & .004 \\
& $\mathrm{~N}$ & 5 & 5 \\
Communication breakdowns & Pearson Correlation & .839 & \\
& Sig. (2-tailed) & .004 & 1 \\
& $\mathrm{~N}$ & 5 & 5 \\
\hline
\end{tabular}

From the analysis above, it shows that the probability value (0.04) is less than the alpha value (0.05), the researchers accept the alternative hypothesis and conclude that there is a significant relationship between self-interest and communication breakdown in the selected tertiary institutions in Edo State with a correlation value of 0.839 .

\section{Conclusion and Implications}

The study examined the relationship between organisational politics and workplace conflict in the selected tertiary institutions in Edo State. Having done the analysis, the findings of the study revealed that there is a positive significant relationship between self-interest and communication breakdown of selected tertiary institutions in Edo State. From the findings of this study, the researchers conclude that organisational politics leads to workplace conflict if not well managed since there is a positive significant relationship between self- interest and communication breakdown in the selected tertiary institutions in Edo State. It is recommended that the management of tertiary institutions should put more effort in the supervision of staff so as to manage the extent/level of organisational politics. This is expected to directly increase employee performance, effective communication and employee output.

\section{References}

Adams, P.J. (1999). Global concentrations of tropospheric sulfate and nitrate. Journal of Geophys. Res, 104, 13791 - 13823.

Amusan, A.A. (2006). Determination of the spatial distribution of Neochetinaeichhorniae on water hyacinth. Journal of Research in Bioscience, 2(2), 25 - 27.

Anderson, E. (2004). Organisational politics, job attitudes, and work outcomes: Exploration and implication for the public sector. Journal of Vocational Behaviour, 57, $326-347$.

Anthony, K. \& Cleveland, J. (2009). Understanding Performance Appraisal: Social, Organisation and Goal-Based Perspectives, California: SAGE Publishers.

Baron, D. L. (2009). In Good Company: How Social Capital makes organisation Work, Cambridge: Harvard Business School Press. 
Belo, A. (1998). The legal framework of student unionism in Nigeria. In Committee for the Defence of Human Rights (eds). Nigerian Students and the Challenges of Leadership, Lagos: CDHR.

Blau, P. (1964). Power and Exchange in Social Life. New York: Wiley.

Broman, R.J. (2007). Development of a measure of workplace deviance. Journal of Applied Psychology, 85: $349-360$.

Casio, Z.S. \& Aguinis, A.S. (2005). Fairness reduces the negative effects of organisational politics on turnover intentions, citizenship behaviour and job performance. Journal of Business and Psychology, 20, $175-200$.

Dana, A.S. (2003). Limiting the contribution of open scientific literature to the biological weapons threat. Journal of Homeland Security, 3(2), 45 -60.

Drory, Z.S. (2006). Fairness reduces the negative effects of organisational politics on turnover intentions, citizenship behaviour and job performance. journal of Business and Psychology, 20, 175 - 200.

Drucker, P. (2011). People and Performance Management, USA: Harvard Business Press.

Durbin, E. (2001). Strategic Pay: Aligning Organisational Strategies and Pay Systems, San Francisco: Jossey-Bass.

Ejiogu, A. (2000). Morality and National Development. A Publication of the National Organisation Agency, No. 2.

Ellis, M.V. (1991). The Unificationist View: A Context for Validity, U.S.A.:Vanhouse Press.

Eze, R.P. (2011). The relationship of organisational politic and support to work behaviours, attitudes, and stress. Journal of Organisational Behaviour, 18, $159-180$.

Ferris, G.R. and Kacmar, K.M. (1992). Perceptions of organisational politics. Journal of Management, 20(3), $194-202$.

Ferris, G.R. and Kacmar, K.M. (2011). Perception of organisational politics. Journal of Management, 18, 93 - 116.

Ferris, G.R., Russs, G.S. and Fandt, P.M. (1989). Politics in organisations. In R.A. Giacalone and Rosenfeld (Eds.), Impression Management in the Organisation, Hillsdale, NJ: Lawrence Erlbaum.

Gerardi, K. (2011). Financial Deregulation and Innovation, Chicago: Jeremy Press.

Guerico, R.J. (2010). Role conflict and ambiguity as critical variables in a model of organisational behaviour. Organisational Behaviour and Human Performance, 7, 467505.

Hickman, R. (2010). Why We Make Art and Why it is Taught, Bristol: Intellect.

Hsee, K. \& Hastie, R. (2006). Preference reversals between joint and separate evaluation of options: A review and theoretical analysis. Psycho. Bulletin, 125, 5760591.

Kacmar, K.M. (2011). Discriminating among organisational politics, justice, and support. Journal of Organisational Behaviour, 22, 347 - 366.

Lamner, W. (2009). Phrases to Freedom, USA: Booksurge Publishing.

Marshall, E. (2004). Strategies and Techniques for Selling your Fiction: USA: Writers Digest Books.

Mitchell, C. \& Weber, (2002). Conflict Resolution in Mexican-origin Couples: Culture, Gender and Marital Quality, New Haven, Yale: University Press.

Motowidlo, P.S. (2004). Exchange fairness and employee performance: An examination of the relationship between organisation politics and procedural justice. Organisational Behavour and Human Decision Processes, 94, 1 - 14.

O'Brien, K.E. and Allen, T.D. (2008). Relative importance of correlates of organisational citizenship behaviour and counterproductive with behaviour using multiple sources of data.Human Performance, 21, $62-88$. 
Odewumi, S.G. (2003). Towards a more productive university education in Nigeria: Some strike avoidable strategies. Paper presented at the National University Stakeholders' Forum at Abuja, Nigeria.

Okoli, C. (2010). Organisation Theories and Practice, Lagos: Ava Press.

Olorode, L. (2001). Democratic imperative and higher education in Nigeria: The quest for social justice. Proceedings of the 12th General Assembly of the Social Science Academy of Nigeria, 2(3), $29-36$

Oloyede, I.B. (2009). Towards free and fair elections in Nigeria: The public relations dimension image maker. Nigerian Institute of Public Relations (NIPR), Ogun State Journal, 2(8), $71-76$.

Onyeonoru, I. \&Bankole, A. (2001). Conflict management and university sustainability: The role of administrators and campus unions. Proceedings of the 12th General Assembly of Social Science Academy of Nigeria, 134 - 138.

Pfeffer, R.S. \& Bozeman, D.P. (2008). The social setting of work organisation: Politics, justice, and support. Managing the social climate of the workplace, Westport CT: Quorum.

Sonnetag, E. (2003). Development in Organisational Politics, Cheltenham: MPG Books.

Udoye, C.I. (2011). An investigation of patient modifying factors. Journal of Contemporary Dental Practice, 2(1), $301-304$.

UNESCO (1997). Some thoughts on the reform of higher education in Nigeria. Paper presented at African Regional Consultation Preparatory to the World Conference on Higher Education, at Dakar, Senegal.

Uzoigwe, J. (2009). Nigeria foreign policy and diplomatic disarray. African Journal of International Affairs, 1(1), 59 - 64.

Vigoda, A.P. (2002). Development and validation of a questionnaire for measuring perceived political consideration in performance appraisal. Journal of Organisational Behaviour, 17(2), $179-190$.

Viswesvaran, (2001). Handbook of Industrial Work and Organisational Psychology, London: Sage Publishing.

Wilson, R.D. \& Judge, T.A. (2012). Person-organisation fit and the theory of work adjustment: Implications for satisfaction, tenure, and career success. Journal of Vocational Behaviour, 44, 32 - 54.

Wiyy, D.E. (2009). Perceptions of organisational politics scale (POPS): Development and construct validation. Educational and Psychological Measurement, 51, 193 - 205.

Yaqub, N. (2001). Higher education in Nigeria in perspective. Paper presented at the 12th General Assembly of the Social Sciences Academy of Nigeria. 